\title{
THE INTERPRETATION OF SECTION 15 OF THE IMMIGRATION APPEAL BOARD ACT
}

\author{
WILLIAM JANZEN * and IAN A. HUNTER**
}

\begin{abstract}
Delegation of discretionary authority to subordinate agencies and tribunals is an increasingly necessary and frequent element of the administrative process. One example of delegated discretion is the power given to the Immigration Appeal Board under Section 15 of the Immigration Appeal Board Act; the Board may stay or quash deportation orders on grounds stipulated in the section. The authors critically examine the Board's interpretation of the enumerated grounds in order to establish the nature of the Board's policy in applying the section. Their analysis of recent Board decisions with respect to Section 15 reveals that under Sections 15(1)(a) and 15(1)(b)(ii) the Board has "evolved impressive guidelines", but that their decisions under Section 15(1)(b)(i) are open to some criticism. The authors suggest that the Board's interpretation of Section 15(1)(b)(i) may actually have "thwarted the intention of Parliament." In this connection, they question the Board's preoccupation with its own image as a court. However, they conclude that, on the whole, the Board has exercised its discretion in line with the intention of Parliament that humanitarian and compassionate consideration be applied to specific cases, and has evolved guidelines which enable it to carry out this intention.
\end{abstract}

\section{INTRODUCTION}

The exercise of discretionary powers in the regulation of public affairs continues to be a subject of serious debate. It has long been held that discretionary powers allow for irregularities and inconsistencies and that the "... maximum substitution of rules of law for discretion is desirable." 1 More recently, however, it has been argued that the traditional legal process lacks the flexibility, speed and expertise that is required in a modern complex society and that some measure of discretion is therefore necessary. To guard against the excesses of unbridled discretion, this argument continues, authorities that have discretionary powers should regulate themselves with a system of internal rule-making. ${ }^{2}$ With such a procedure, it is claimed, the predictability and "uniformity in decisions," that characterized the traditional legal process could be preserved, while at the same time allowance would be made for the merits of each individual case.

In dealing with the discretionary powers of Section 15 of the Immigration Appeal Board Act, the Immigration Appeal Board has tried to implement a procedure of this type. In a Special Lecture to the Law Society of Upper Canada in 1971, the Chairman of the Board said that the discretionary powers of section $15:^{3}$

$\ldots$ must always be exercised on the merits of each individual case, ... [however] it is obviously highly undesirable if decisions reached on identical factual situations go opposite ways. The only way to avoid this, in my view, is to evolve certain fundamental philosophical and legal principles as guidelines for the exercise of discretion.

*Ph.D. Candidate, Carleton University.

**Assistant Professor of Law, Carleton University.

1 Breital, Controls in Criminal Law Enforcement, 27 University of Chicago Law Review 427.

2 This idea is not new although it has received more attention since the recent book by Professor K. C. Davis, Discretionary Justice: A Preliminary Inquiry (1969).

3 Scott, Immigration Inquiries and Appeals From Orders of Deportation, Special Lectures of the Law Society of Upper Canada, (1971). 
True to the Chairman's intentions, certain guidelines have evolved. However, due to a lack of research and writing in this field, these guidelines have not been made known, even to members of the legal profession. This study, it is hoped, will help to fill this void. It will analyze the available decisions that the Board has made under section 15 and try to identify the principles that have served as guidelines in the exercise of its discretion. ${ }^{4}$ Before going to the statute and the cases, however, it may be useful to survey, in brief, the legislative history of the discretionary powers of the Act. This will provide both an understanding of the legislative intent and a standard by which the rules of the Board can be evaluated.

\section{THE LEGISLATIVE HISTORY OF SECTION 15}

In contrast to that of many public authorities, the need for discretionary powers in immigration authorities has seldom been questioned. In 1967, Mr. John Munro, then Parliamentary Secretary to the Minister of Immigration, stated, as he introduced the proposed Immigration Appeal Board Act to the House of Commons: ${ }^{5}$

No immigration law can be both enforceable and fair unless it provides a considerable area of discretion in its operation. The law establishes general rules. . . . they must be capable of being tempered in their application, according to the merits of individual cases. There will sometimes be humanitarian or compassionate reasons for admitting people who, under the general rules, are inadmissible.

Opposition spokesmen agreed. Mr. David Lewis said: ${ }^{6}$

The important question in this legislation is: has the Appeal Board under this legislation the authority to act compassionately, to use its discretion, to consider the particular circumstances affecting the human being before them?

Mr. R. A. Bell and Mr. Rene Tremblay, both former Immigration Ministers, emphasized the need for broad discretionary power as well.

In spite of a strong and unanimous agreement on the desirability of discretionary powers, there was substantial debate regarding the level at which such powers should be posited; should they be delegated exclusively to the Immigration Appeal Board, or should the Minister preserve a residuum of discretionary authority? Prior to 1967 , these powers had been restricted to the Minister, although the Board was able to make recommendations to the Minister. ${ }^{7}$ In reviewing the earlier system, Mr. Tremblay said: 8

... ministerial discretion is the very basis of the Immigration Act. There is not one section... which does not show that the minister may, at his discretion, reverse the decisions handed down previously at the administrative level.

It is not surprising that this system gave rise to serious problems.

4 In his Report on Immigration Part $I$ (Department of Immigration, Government of Canada, 1966) which contributed directly to the formation of the Board, Mr. Joseph Sedgwick, Q.C., stated: "I would expect that an independent board exercising discretion ... would soon, on the basis of precedent, evolve intelligible and reasonable guidelines which would be made known to members of the legal profession and others particularly interested in immixration matters as well as to the public generally." It should also be noted, at this point, that although a majority of the cases that this study will analyze come from the published volumes of Immi ination Appeal Cases, a substantial number of unreported cases were made available to the authors through the kind generosity of Mr. M. Parent, the legal officer of the Board. This study does not include cases after June 1972 .

s (1967) 12 H.C. Deb. 13267.

- Id. at 13283.

7 Scott, supra, n. 3 at 118.

- H.C. Deb., supra, n. 5 at 13290. 
Mr. Bell, drawing on his experience, described these very succinctly when he said: ${ }^{9}$

In no department of government is a Minister . . . called upon to exercise so many discretions or subject to so many pressures-pressures from members of Parliament, from candidates, from ethnic groups, from religious and philanthropic organizations....

It was in the face of these problems that the government commissioned Mr. Joseph Sedgwick, Q.C., to "prepare a second report on ministerial discretion in the case of the Minister of Immigration."10 And in making this report, $\mathrm{Mr}$. Sedgwick recommended that: ${ }^{11}$

... the Immigration Appeal Board should be vested with final authority, subject to a right of appeal to the Courts. ... To make appeals to the board subject to review and to final determination by the minister is to render the board essentially sterile.

Although the Act followed this recommendation and posited the discretionary powers entirely with the Board, Mr. Bell had misgivings about this arrangement too. He argued for retaining a limited and wellguarded residuum of ultimate discretion with the Minister: ${ }^{12}$

I know there are many good persons in Canada today, sir, making good citizens who were admitted by me in the exercise of ministerial discretion, or should I say ministerial instinct, and who I doubt very much would ever have gained admission from any board, however enlightened and superior that board might have been. It is a simple fact of life that politicians must learn to take chances, chances which others in less rigorous occupations do not take.

In spite of this objection, the Immigration Appeal Board Act was proclaimed in force on November 3,1967 , with exclusive discretionary powers vested in the Board. ${ }^{13}$

\section{SECTION 15 AND THE CASES}

\section{The Statute}

\section{The Immigration Appeal Board Act states that: ${ }^{14}$}

Where the Board dismisses an appeal against an order of deportation or makes an order of deportation pursuant to paragraph 14(c), it shall direct that the order be executed as soon as practicable, except that the Board may,

(a) in the case of a person who was a permanent resident at the time of the making of the order of deportation, having regard to all the circumstances of the case, or

(b) in the case of a person who is not a permanent resident at the time of the making of the order of deportation, having regard to

(i) the existence of reasonable grounds for believing that if execution of the order is carried out, the person concerned will be punished for activities of a political character or will suffer unusual hardship, or

(ii) the existence of compassionate or humanitarian considerations that in the opinion of the Board warrant the granting of special relief,

direct that the execution of the order of deportation be stayed, or quash the order and direct the grant of entry or landing to the person against whom the order was made.

Id. at 13280.

10 Id. at 13294. His firat report dealt with another aspect of immigration law.

"Sedgwick, supra, n. 4 at 8.

12 H.C. Deb., supre, n. 5 at 13282.

${ }^{13}$ Two cases dealing with the Supreme Court's review of the Board's exercise of its discretion are Boulis v. Minister of Manpower and Immigration (1972) 26 D.L.R. (3d) 216 and Grillas v. Minister of Manpower and Immigration (1972) 23 D.L.R. (3d) 1.

14 Immigration Appeal Board Act, R.S.C. 1970 c. 1-3, 8.15. 
Although the legislative history of the Act shows clearly that Parliament intended to make compassionate and humanitarian considerations applicable to the cases, there are differences between the three parts of the statute which together with the Board's construction of them, determine that these considerations cannot be applied in a uniform way. The first distinction is between subsection (a) which applies to permanent residents and subsection (b) which applies to all other persons. In describing the differences in the nature of the discretionary powers of these two subsections, the Board has stated:15

In the case of a permanent resident, the matters to be considered will cover a very wide range as the Board may exercise its discretionary powers 'having regard to all the circumstances of the case. ...' In all other cases the matters to be considered by the Board are circumscribed by the Act and are limited to determining whether reasonable grounds exist for believing that if the deportation order is carried out 'the person will be punished for activities of a political character or will suffer unusual hardship' and also whether there exist compassionate or humanitarian considerations that in the opinion of the Board warrant the granting of special relief.

The second distinction is between subparagraph (i) and subparagraph (ii) of subsection (b). In her Special Lecture, the Chairman said:16

... I would like to draw your attention to the distinction between section 15(1)(b)(i)which may be mandatory and not discretionary, and where the wording implies a high standard of proof, and section $15(1)(b)(i i)$, which is clearly discretionary and much more general in scope.

According to this outline then, subsection (a) applies to permanent residents and calls for the consideration of the widest range of circumstances; subsection (b)(i) applies to persons who are not permanent residents and makes no explicit grant of discretionary power and subsection (b)(ii) also applies to persons who are not permanent residents but there is an explicit grant of discretionary power here. This outline is of course very general and the significance of these distinctions is in fact quite marginal but they do help to provide a conceptual framework for the following analysis of the Board's decisions under each of the three parts.

2. Section $15(1)(a)$

$\ldots$ in the case of a person who was a permanent resident at the time of the making of the order of deportation, having regard to all the circumstances of the case.

Although this section appears to cover a large group of people, there are only two decisions under it that are available and in both cases, the Board has granted relief. In one case the Board stated: ${ }^{17}$

The appellant, aged 33, is a married man having the whole of his family with him in Canada; by trade he is a brick layer and construction laborer and has been steadily employed since his coming to Canada and having the full confidence of his employer; in 1968 the appellant bought a house with a $\$ 4,000$ down payment and would have now savings in the amount of $\$ 300$ or $\$ 400 ; \ldots$ there is evidence that his family is a normal one. . . . The execution of the order of deportation would mean that the head of the family and one of his sons will be deported to Italy while the other dependents, the wife and child, will be permitted to stay in Canada. . . . Taking into account all the circumstances of the case ... the Board finds reasonable grounds to exercise its discretion.

In the other case, the issue was whether the information, by which

\footnotetext{
1s Gioulekas v. Minister of Manpower and Immigration (1969) 1 I.A.C. 41.

16 Scott, supra, n. 3 at 132.

17 Folino v. Minister of Manpower and Immigration (1969) 1 I.A.C. 177.
} 
the appellant had gained entry into Canada, was false and misleading. The information in question related to his marital status in his home country and in its decision the Board stated: ${ }^{18}$

... je suis satisfait que . . . l'appellant ne s'est pas trompe en croyant et n'a pas trompé en déclarent etre, a tout fin pratique et que de droit, être célibataire puisque son mariage est nul et de nul effet au regard de la loi du lieu de son mariage.

The Board recognized that some doubts remained regarding the documents that the appellant presented, but it held that ". . . le doute doit être tranché en faveur de l'appelant qui était présent et qui a cté soumis à un interrogatoire et à un contre-interrogatoire serrés." 19

The diversity of reasons that these statements allude to, makes it impossible to identify the operating guidelines. However, in preparing to appear before the Board on behalf of a person coming under this section it would be advisable to check the guidelines which the Board uses in section 15(1)(b)(ii) and which this article discusses further on. In her Special Lecture, the Chairman makes several references to section 15 (1)(a) and (b)(ii) in the same context, suggesting that the considerations to be applied in the two sections are quite similar. ${ }^{20}$

\section{Section 15(1)(b)(i)}

... the existence of reasonable grounds for believing that if execution of the deportation order is carried out the person concerned will be punished for activities of a political character or will suffer unusual hardship.

According to the Board's construction of this subparagraph, it makes no explicit grant of discretionary power. In the Pagan case the Board stated, ". . . in section 15(1)(b)(i), there is no element of discretion." 21 And in the Agouros case, it held:22

... if proof is made of one or both of the conditions very specifically set out in section $15(1)(b)(i)$, and there is no ground to reject such proof, the Board must take action ...; it has a duty and obligation to do so. There is no element of discretion whatsoever except in the degree of remedy to be granted.

In spite of this construction, it cannot be denied that a sizeable measure of discretion arises from the interpretation that is given to terms within this subparagraph. This article will now deal with the Board's interpretation of the three critical terms of this subparagraph.

(a) "... the existence of reasonable grounds for believing. ..."

The interpretation of this term prescribes the standard of certainty to which the occurrence of the events described in the other two termspunishment for activities of a political character or suffering unusual hardship-has to be established. In defining this standard, the Board appears to have developed three guidelines. The first is that the onus

1s Saini v. Minister of Manpower and Immigration (unreported) Septernber 16, 1970 at 5.

19 Id. at 5.

${ }^{20}$ Scott, supra, n. 3 at 131-132.

21 Pagan v. Minister of Manpower and Immigration (unreported) April 11, 1972 at 30.

22 Agouros v. Minister of Manpower and Immigration (1970) 2 I.A.C. 46. The construction of this subparagraph is also in accord with the Board's interpretation of the term "may" which appears at the beginning of the section and applies to both subsections. The Board recognizes that the Interpretation Act provides that "may" is "to be construed as permissive." However, with the support of several well-established cases, the Board concludes that "... when a statute authorizes the doing of a thing for the sake of justice. ... the word 'may' means 'shall'." In referring to the case of Justin v. Town of Brampton (1929) 36 O.W.N. 114 the Board notes, "there the Court held that the word 'may' did not confer merely a discretionary or enabling power, but imposed an obligation to... grant relief unless grounds are shown for rejection. This would appear to be the correct interpretation of the word 'may' in Bection 15(1)." Id. at 45. 
of establishing certainty rests entirely with the appellant. In the Phuoc case the Board asked: ${ }^{23}$

Has the appellant adduced the evidence, of which he has the onus, in support of his

allegation? Has he proved the existence of reasonable grounds for believing ...

Similarily in the Pagan case, the Board said "the appellant must satisfy the heavy burden of proof imposed on him." 24

The second guideline refers to the degree of certainty. The Board states that this is "balance of probability" but its strong emphasis sug. gests that it is something more. In the Lau case the Board notes "... the mere balance of convenience can hardly be considered as foundation ...",25 and then goes on to ask whether ". . . the person will be (not may be) punished. ..."26 In the Agouros case, the Board noted "... the burden of proof on the person concerned in respect of this subsection, is heavy, by virtue of the precise wording used."27 And in the Pagan case the Board states: ${ }^{28}$

This is civil proof, of course-balance of probability - . .; the phraseology is however significant: 'reasonable grounds for believing that he 'will' (not may) be punished for activities of a political character'.

The third guideline for establishing certainty refers to the more substantive definition of "reasonable grounds." The Board has made several general statements that point towards such a definition. It has recognized that, "proof establishing reasonable grounds for believing that an event will occur in the future must be made on the basis of past or current events." 29 It has also stated ". . . the existence (which is an objective fact) of reasonable grounds (feeling is not reasoning). . .."30 Aside from these general statements however, a very basic part of this question is closely related to the question of definition. That is, the question of whether "punishment" will occur, or whether "unusual hardship" will be suffered, is inseparably related to the definitions of "punishment" and "unusual hardship". ${ }^{31}$ Because of this interrelationship, the question of certainty is carried over into the following discussions which deal more specifically with questions of definition.

(b) "... will be punished for activities of a political character...."

This requires the Board to determine whether the appellant will be punished for activities of a political character if the order of deportation is carried out. Clearly, it requires a definition of both "punishment" and "activities of a political character".

The interpretation of "punishment" that arises from the cases suggests that its meaning has been restricted to "punishment by the state and according to law". In a 1968 case, the appellant was a South African coloured journalist who had acquired gainful employment in Canada

\footnotetext{
23 Phuoc v. Minister of Manpower and Immigration (1970) 3 I.A.C. 82.

24 Pagan, supra, n. 21 at 14.

${ }^{25}$ Lau v. Minister of Manpower and Immigration (1970) 2 I.A.C. 75.

28 Id. at 76.

27 Agouros, supra, n. 22 at 46.

29 Pagan, supra, n. 21 at 15.

29 Id. at 15.

30 Phuoc, supra, n. 23 at 82

31 To clarify this point, an analogy to the difficulty of defining "aggression" in international affairs might be suggested. There, it seems, the question of whether "aggression" did or did not occur rarely depends on whether a given set of events did or did not take place; instead it usually depends on whether those events constitute "aggression".
} 
but who was unable to meet the requirements of landed immigrant status. Here the Board granted relief on the evidence that under South Africa's General Law Amendment Act, the South African government could subject him to various pressures including imprisonment and on the evidence, supported by the opinion of two professors in Canadian universities who had recently come from South Africa ". . . that when people have done the sort of thing that the Appellant has done . . . they are immediately subjected to ... this treatment." 32

Although the Peterson case suggests quite strongly that an appellant has to show that his punishment will be "by the state and according to law," the Phuoc case, decided in 1970 does not support the emphasis on law. In this case the appellant was a South Vietnamese who claimed that if returned, he would be punished for his opposition to the war. The Board heard evidence from Professor Gary, a well-known expert on Asian affairs who said "en mon âme et conscience, je crois que renoyer ce jeune homme ... au Vietnam serait . . . (lui) candamner à la privation de la liberté, si ce n'est pas privation de la vie."33 This opinion was supplemented by a recognition that ". . . in the particular circumstances of the Vietnam conflict ... it would be reasonable to believe that for such activity the appellant would be punished. . .."34 The Board's decision to grant relief in this case appears to rest on the opinion of an expert supplemented by a general knowledge of the particular situation.

In a decision in 1972, however, the Board returned to the earlier position and stated it with particular emphasis. In this decision the appellant, a former student leader in the Puerto Rican independence movement, was charged with the murder of a police officer during a "riot" at the University of Puerto Rico. When it was found that he had come "into Canada by reason of false or misleading information," he was ordered deported. In appealing this order, ten witnesses, including a Puerto Rican lawyer and former judge, testified for him. They were unable to prove the existence of a law specifically directed against "independentista", however: ${ }^{35}$

All the witnesses expressed the opinion that if Humberto Pagan were sent back to Puerto Rico he would, as an independentista, be killed before he came to trialor at best suffer irreparable injury.

The Board acknowledged this evidence but dismissed it, saying that it ". . . is not relevant to this portion of section $15(1)(b)(i) . . . "$ Instead, it turned to several dictionary definitions of the word "punish" and found that: 36

All these definitions imply punishment by the authority designated for that purposethe state, within or according to the law of that state. Section $15(1)(b)(i)$ may be interpreted to include punishment by the state both legally and extra-legally, but there is no evidence of either element in the instant appeal.

Apart from this ambiguous reference to "extra-legal" punishment by

\footnotetext{
32 Peterson v. Minister of Manpower and Immigration (1969) I I.A.C. 33

${ }^{33}$ Phuoc, supra, n. 23 at 83.

34 Id.

3s Pagan, supra, n. 21 at 14

36 Id. at 16.
} 
the State, the Board's interpretation that punishment has to be by the State and according to law now appears to be complete. ${ }^{37}$

The cases in which the Board has interpreted "activities of a political character," suggest that such activities are defined as public challenges to a government's authority. Such challenges could come in the form of writings, speeches, or actions as by demonstrations or by active membership in a political party or movement. Private forms of opposition and protest, like military desertion, have not been recognized as 'activities of a political character'.

In the Phuoc case, where the appellant had edited a Review for Vietnamese students in Canada, the Board stated: ${ }^{38}$

If this evidence reveal[s] that the appellant, by his actions, his statements or his writings has challenged his government's position, it would have to be concluded that his challenge, in the particular circumstances of the Vietnamese conflict, is clearly of a political nature....

In this case, the Board found that as a result of his public statements and editorials, his "... opposition to the war was well known ..." and that "... if the deportation order is carried out the appellant will be punished for activities of a political character. . . . ${ }^{39}$ Accordingly, it granted relief.

In the Peterson case, where the appellant had publicly criticized his government's apartheid policy while in Canada, the Board heard testimony from two South African born university professors that Peterson's conduct "... constitutes in the eyes of the South African Government an act of nothing less than treason." This too was recognized as an activity of a political character. ${ }^{40}$ Similarly in the Bourret case, the Board appeared to accept the argument that the appellant's ". . . expressed violently hostile opinions of the Cuban regime" constituted activities of a political character, although in the result it held that there was insufficient evidence as to the certainty that punishment would follow deportation. ${ }^{41}$ These cases suggest that criticism of government policy abroad, by writing or speech, likely to result in reprisals if deportation is carried out, will be recognized by the Board to be an "activity of a political character".

The Board has also indicated that actions, either by public demonstrations or by active and prominent membership in a political party may be construed as an "activity of a political character". Thus, in the Pagan case, activity of a political character was established by Pagan's membership in "the executive committee of the federation of the stu-

37 It might be suggested that "extra-legal" punishment by the State means punishment by the State or by some agency of the State that is not authorized by law. However, this cannot be the intended meaning since that is precisely what was dismissed in notes 35 and 36 above. Two other decisions in late 1971 that show the Boand's reliance on law are, Aly v. Minister of Manpower and Immigration (unreported) December 1, 1971; and Daniolos v. Minister of Manpower and Immigration (unreported) November 10, 1971. In the Aly case the Board dismissed the appeal because the appellant failed to prove the existence of a certain military law to support his claim that he would be punished for desertion. And in the Daniolos case, the appeal was upheld because the appellant was able to present strong evidence that as a conscientious objector, he would be im. prisoned under the Greek Code of Military Recruitment. Since neither desertion from military service nor conscientious objection to military service are recognized as "activities of a political character," the Board dealt with both of these cases in terms of unusual hardship. Nevertheless, they do emphasize further the Board's reliance on law.

3s Phuoc, supra, n. 23 at 83.

39 Id. at 83.

4 Peterson, supra, n. 32 at 35.

4 Bourret v. Minister of Manpower and Immigration (1970) 2 I.A.C. 74. However, the Board did grant relief on other grounds. 
dents for independence ... [which would] . . . carry on demonstrations in favour of Puerto Rican Independence" 42 and by the general recognition of him as a prominent leader in this movement. Since Pagan failed to prove that he would be "punished", according to the Board's definition of punishment, he was unsuccessful in using this as a ground for relief. Similarly in the Dieujuste case, the appellant had been a member of a political movement committed to the overthrow of the Duvalier Government of Haiti. ${ }^{43} \mathrm{He}$ too failed in using this as a ground for relief. But the reason for the failure in this case was that "he is not of such prominence as to have been drawn to the attention of the political police, therefore it is questionable if on his return he will come to their attention." 44 And in the Gioulekas case the Board stated "[t]he appellant does not appear to be a person of such prominence as to be subject to the constant surveillance of the regime." 45

Regarding the more private forms of opposition or protest-there are two cases in which the Board has rejected claims that desertion from military service is an "activity of a political character." 46 It has also rejected the claim of a Greek appellant that his "sympathy with the Royalist cause" constituted an activity of a political character. ${ }^{47}$

(c) "... will suffer unusual hardship."

The critical issue here is the meaning of "unusual". In interpreting it the Board has asked whether the hardships, which the appellant claims he will suffer if the deportation order is carried out, are unusual in terms of his situation in his home country. ${ }^{48}$ In accordance with this formulation of the question and the principle that it implies, the Board has held that the hardships of obligatory military service in one's home country are not unusual. In the Tsemanakis case the Board stated:49

. . . it cannot be said that the appellant would suffer unusual hardship by having to do his military services. Mr. Tsemanakis would be doing nothing more than what thousands of his compatriots are forced to do every year under existing Greek law.

Secondly, the Board has held that economic hardships, by themselves, are not "unusual". In the Bastas case the Board stated that it:50

... could not reasonably find that the loss of a business or a job or other advantage acquired while illegally in Canada is unusual hardship; neither could the economic situation of the appellant's country ... be considered as such.

In the Kritikos case, the appellant: 51

During the illegal stay ... in Canada, ... succeeded in attaining a very considerable

12 Pagan, supra, n. 21 at 15.

42 Dieujuste v. Minister of Manpower and Immigration (unreported) June 10, 1969 at 8.

"Id.

4s Gioulekas, supra, n. 15 at 45.

is Aly, supra, n. 37 and Caudill v. Minister of Manpower and Immigration (1969) 1 I.A.C. 108.

17 Klempatsanis v. Minister of Manpower and Immigration (1970) 1 I.A.C. 5.

10 It is important to note that the question does not simply ask whether the hardship of the appellant would be unusual in his home country. If this was the question, then "unusual hardship" might be construed as anything below average in that country. By avoiding this dilemma however, the Board has fallen into another one, in that its formulation of the question makes it almost impossible to conceive of a hardship that would be recognized as unusual.

49 Tsemanakis v. Minister of Manpower and Immigration (1970) 3 l.A.C. 135. In a more general statement regarding the requirement of military service, the Board has held that "an obligation on the part of the person concerned to undertake military service on behalf of the country of which he is a citizen is not a ground ... under either section 15(1)(b)(i) or (ii)." Agouros, supra, n. 22 at 48.

so Bastas v. Minister of Manpower and Immigration (unreported) October 20, 1970 at 2.

s1 Kritikos v. Minister of Manpower and Immigration (unreported) February 25, 1971 at 2. 
amount of assets and $\ldots$ is, without doubt, in a far better financial position than he was when he arrived in Canada. ${ }^{51}$

However, the Board did not regard the loss of these assets as an "unusual hardship". In the Lau case, the appellant had become a partner in a successful restaurant business but again the Board held that ". . . even if he has to sell his share of the business at a loss, this does not constitute an unusual hardship."52

A third area to which the Board has applied this principle is the hardship of suffering the penalties for breaking a law in one's own home country. In the Peters case it was stated that “.. . suffering the penalty of a relatively civilized country for a law you have broken is not exactly an unusual hardship." 53 In this case the appellant had been "convicted of a crime involving moral turpitude; namely assault. . .."54 The ruling has also been applied to the punishment or hardship for military desertion. In the Caudill case the Board stated:55

He may well be liable to punishment for being an absentee without leave from the United States Marine Corps. Such punishment is certainly not ... 'unusual hardship'.

And in the Aly case the Board said: "even if the appellant is subject to being court-martialled as a deserter. ... The court does not find that there is unusual hardship in this case." ${ }^{56}$ The Board has also applied this ruling to the claims of many ship deserters. In the Dakovic case, the Board recognized that the appellant's "greatest fear of persecution .... (is) for breaking the terms of the Articles he signed when joining the vessel."57 However, the Board did not interpret such persecution as unusual hardship.

A fourth area to which the Board has applied the principle covers the hardships suffered due to the legal restrictions imposed on those of the appellant's racial grouping in his home country. Although there is only one case that illustrates this position, the Board elaborated on this at some length. In this case, where the appellant was a coloured journalist from South Africa, the Board stated: 58

... the doctrine of apartheid ... imposes a mode of life circumscribed by restrictions

52 Lau, supra, n. 25 at 77. The Aina case suggests however that this principle is not inflexible. Aina v. Minister of Manpower and Immigration (1969) 1 l.A.C. 46. In this case, it appears that one of several reasons for the granting of relief rose out of the economic hardships that a deportation would impose.

53 Peters v. Minister of Manpower and Immigration (unreported) November 18, 1970. The words in this quotation are not those of the Board. While the Board seems to accept their intent, its own words are slightly less categorical. It says: ". . . the potential length of a sentence, and its possible harshness in comparison with Canadian standards, cannot, in the circumstances of this case, be considered in determining 'uniusual hardship'... . The fact that he will be sentenced for the offence for which he was convicted, and possibly tried on the other two offences, if he is returned to the United States, cannot be held to be unusual hardship, of which the standards are those of the home country, not of Canada." Id. at 15.

54 Id. at 1 . The Board stated also that the "crime ... must be recognizable as a crime in Canada." Id. at 9.

ss Caudill, supra, n. 46 at 115 .

so Aly, supra, n. 37 at 2.

57 Dakovic v. Minister of Manpower and Immigration (unreported) December 1, 1970 at 2.

so Peterson, supra, n. 32 at 35 . Although the Board stated this position very clearly, it did grant relief in this case, on what appears to be a combination of humanitarian considerations and the likelihood of punishment for activities of a political character. A similar ruling appears in the Pagan case, which deals with the hardships of a political grouping, rather than with those of a racial or religious grouping. Here the Board holds that "Mr. Pagan is no worse off than any other independentista, and he cannot claim that he will suffer unusua hardship on this account." This judgment has further significance because the Board goes on to deal with a sizeable body of evidence which suggests that "he is something more than a member, or even a leader, of the Puerto Rican Independence Movement" and that his hardships will be unusual for this reason. But the Board concludes that "there is no direct evidence, however, that this will (not may) place him in a worse position, or cause him to suffer unusual hardship." Pagan, supra, n. 21 at 19 
and regulations on both the black and coloured population . . . in a manner with which most Canadians do not agree. . . . However, there was no evidence adduced ... that the appellant will himself suffer unusual hardship, over and above that shared and suffered by all 'coloureds' if he should be returned to South Africa.

A very significant exception to these rulings is the Daniolos decision. In this case the appellant was a citizen of Greece, a devout and longstanding member of Jehovah's Witness faith and consequently, a conscientious objector to military service. However, the Greek Code of Military Recruitment allowed for no exceptions and the Greek Martial Code provided for anyone who refused to serve in the military "the punishment ... five years in prison, ..." and at the end of the prison term, "if he refuses he is again sentenced ..."s9 Counsel argued that the appellant was "seeking religious freedom in Canada ..." and in the result, the Board quashed the deportation order on the ground that if it were executed the appellant would, "suffer unusual hardship".60

It is not entirely clear what this decision means. If the principle established in the Peterson case-that the hardships suffered because of the legal restrictions imposed by the laws of the appellant's home country on the racial grouping of which the appellant is a part are not unusual hardships-is extended so as to include religious groupings, then the Daniolos decision is a striking exception to it. Just as Peterson was no worse off than any other "coloured" in South Africa, so Daniolos was no worse off than any other Jehovah's Witness in Greece. The decision also appears to be an exception to the principle supported by the Peters, Aly, Dakovic and Caudill cases that "to suffer the penalty of a relatively civilized country for a law you have broken is not exactly unusual hardship". The Greek Code of Military Recruitment was definitely a law and Daniolos was deliberately breaking it. To reconcile the Daniolos case with those cases would be to suggest that Greece is not a "relatively civilized country".

The Daniolos decision could also mean that the general principlethat the unusualness of a hardship is determined according to the appellant's situation in his home country-does not apply to the area of religious liberty; that if an appellant can present "reasonable grounds for believing" that circumstances in his home country impose severe hardships on the practise of his religious beliefs, then these hardships will be recognized as "unusual".

\section{Section 15(1)(b)(ii)}

... the existence of compassionate or humanitarian considerations that in the opinion of the Board warrant the granting of special relief.

In contrast to subparagraph (i), which the Board said "contained no element of discretion", subparagraph (ii) is recognized as containing an explicit grant of discretionary power. In her Special Lecture, the Chairman stated:61

. this subparagraph unquestionably gives discretionary power, because of the inclusion therein of the words 'in the opinion of.

39 Daniolos v. Minister of Manpower and Immigration (unreported) November 10, 1971 at 5 . This evidence was given by one who had served with the Recruitment branch of the Greek Army at the rank of Second Lieutenant and who at the time of the hearing was a graduate student at a Canadian University.

so Id.

61 Scott, supra, n. 3 at 130. 
The Board has made several noteworthy statements indicating its general approach to this section. It has said that: ${ }^{2}$

... 'compassionate or humanitarian considerations' is a phrase expressing a rather vague concept and compassionate and humanitarian are hardly opened to satisfactory legal definitions but they are not tantamount to mean sentimentalism or emotionalism....

\title{
It has also stated:63
}

\begin{abstract}
While the definition of 'compassion' implies an element of subjectivity, since emotion is involved, it is clear that no judicial decision or finding, no matter how discretionary, can be based on emotion. The meaning of the words 'compassionate considerations' in this context of section 15(1)(b)(ii) must therefore be taken to be those facts, established by the evidence which would excite in a reasonable man in a civilized community a desire to relieve the misfortunes of another.
\end{abstract}

In applying this section to the cases the Board appears to have relied on three fairly specific considerations: (1) Family considerations, (2) Considerations of "rootedness", and (3) Considerations for hardships arising strictly out of technicalities of law.

\section{(a) Family considerations}

A very important and consistent holding of the Board has been that compassionate or humanitarian considerations are not restricted to the appellant himself: ${ }^{64}$

The scope of section 15(1)(b)(ii) extends to persons other than the person concerned .... While these doubtless cannot be said to extend to the world at large, the wording of the subsection clearly covers the situation of persons in close relationship with the person concerned, whose own future is closely allied with his and whose fate will be directly affected by the decision taken in respect of him.

In view of this holding, it is not surprising that family considerations have become important. Indeed, there are cases where the Board has granted relief out of considerations for the appellant's family even though it felt that the appellant himself did not warrant relief. In the Agouros case, where the appellant had married a Canadian citizen who, at the time of the appeal, was expecting a child, the Board held:65

... insofar as Mr Agouros himself is concerned, there is no evidence which would support the invocation of section 15(1)(b)(ii) on his behalf. However, in the opinion of the Board, the situation of Mrs. Agouros warrants the granting of special relief to the appellant .... To deport the appellant now would involve the lengthy separation of this young couple, and would deprive his wife of the emotional and economic support of her husband at a critical time, i.e. during the birth and infancy of their child. The Board therefore ... orders that the order of deportation ... be quashed.

Similarly in the Progakis case, the Board stated bluntly that it had "... no sympathy for the appellant" but it quashed the deportation order because of "compassion for two Canadian citizens (the appellant's wife and child) who would be very unfavourably affected if the order of deportation ... were executed." 66 In the Chirwa case the Board quashed the deportation order because only in that way could it ". . . assure the continued existence of this family as a viable unit." 67

62 Lau, supra, n. 25 at 76.

C3 Chirwa v. Minister of Manpower and Immigration (1970) 2 I.A.C. 73.

64 Agouros, supra, n. 22 at 47.

65 Id. at 50.

66 Progakis v. Minister of Manpower and Immigration (unreported) December 10, 1970 at 5.

67 Chirwa v. Minister of Manpower and Immigration (1970) 2 I.A.C. 146. 
Since family considerations do influence the Board, it is not surprising that there are attempts to arrange family situations so as to excite the Board's sympathy. Such attempts are not likely to be successful as the Tsemanakis and Bastas cases illustrate. In these cases the facts were similar to those of Agouros and Progakis - marriage in Canada and a pregnant wife-except that the marriages of Tsemanakis and Bastas took place after the deportation orders had been issued, their wives knew of their husbands legal status before the marriages, and their wives were neither Canadian citizens nor deeply rooted in Canada. ${ }^{68}$ In both of these cases the Board refused to grant relief.

The Tsemanakis judgment is also valuable for its extended discussion of the equitable principles that the Board uses in deciding whether to exercise its discretion under section 15(1)(b)(ii). The Board considered ". . . the subjective factors: the appellant's attitude, his intentions, his good faith, his submission to the law or his sincere desire to do so ...." and although unwilling to conclusively impute improper motives to the appellant, the Board was sufficiently suspicious to decline to exercise its discretion in his favour. ${ }^{69}$ In the Bastas case the Board held that ". . . the appellant deliberately and knowingly placed himself in a position which does not merit the granting of special relief."70 Such factors also appear to have been significant in the cases of $A l y$, Dieujuste, Vincent and Lotero-Isaza. ${ }^{71}$

\section{(b) The consideration of "rootedness"}

Related to family considerations is the question of "rootedness". The more deeply "rooted" in Canada the appellant and/or his family, the more favourable are their chances before the Board. The Board has never defined "rootedness" but the cases suggest certain factors that carry weight with the Board.

(1) Citizenship and family ties of the appellant's immediate family: the Progakis and Agouros cases, discussed above, illustrate this.

(2) Length of time in Canada: in the Aina case where the Board granted relief, it stated: ${ }^{72}$

The appellant has been in Canada for a period of six years and his wife for a period of three years. They have made progress and adapted themselves well in this country. They have now established roots here.

(3) Present or future occupational prospects: this is suggested in the above quotation from the Aina case but it is stated more explicitly in the case of Dr. Chung Ming Lu, where the Board said: "the appellants have established roots in Canada, ... the male appellant if deported would

\footnotetext{
68 Progakis, supra, n. 66 at 5; and Bastas, supra, n. 50 at 2.

69 Tsemanakis, supra, n. 49 at 138. At 140 the Board stated: "In the present instance, there is no doubt that the appellant's marriage was celebrated after the appellant had been ordered deported. But does the $e x$ post facto marriage prove that the marriage was contracted in bad faith? Who can prove that the couple did not marry for love? However, even if the appellant was of good faith and did marry for love, is the Court justified in automatically qualifying the appellant for special relief on that ground alone, brushing aside and ignoring the elementary norms of personal responsibility which each individual must accept in a responsible society?" It included, at 141: "Can the Court be accused of lack of compassion, of being inhuman or evading its responsibility in declining this case by suggesting that the appellant and his wife are and must be held responsible for their acts...?"

70 Bastas, supra, n. 50 at 5.

71 Aly, supra, n. 37; Dieujuste, supra, n. 43; Vincent v. Minister of Manpower and Immigration (unreported) May 28, 1971; and Lotero-Isaza v. Minister of Manpower and Immigration (unreported) August 31, 1970.

72 Aina, supra, n. 52 at 52.
} 
not be able to develop and obtain employment commensurate with his academic achievements."73

(4) The presence of relatives in Canada: this factor is especially evident in the appeals that the Board has dismissed. In the Rafik case the Board concluded ". . . he has no close relatives in Canada, no commitments nor has he established such roots here that uprooting would cause him anguish or hardship."74 In the Graham case, it held ". . . the appellant has no roots in this country, no relatives and is not established in Canada."75 Similar references are found in the $A l y$, Vincent and Dakovic, Kim, Lau and Gioulekas cases. ${ }^{76}$

(5) Success in employment has not proven to be an influential factor, at least not by itself. This was made clear in the Kim case where the Board stated: "He has savings of $\$ 4,000$ and appears to be industrious, hardworking and no doubt be better off in Canada than in Korea: however, these are not grounds or reasons for the Court granting special relief."77 The quotation from the Kritikos judgment, noted above, gives further evidence of the weakness of considerations of employment or economics. ${ }^{78}$

\section{(c) Considerations arising strictly out of technicalities of law}

The third kind of consideration is what might be loosely described as considerations for hardships arising strictly out of the technicalities of law. Thus in the Lotero-Isaza case, the appellant had been in Canada, had shown a clear intention of becoming a Canadian citizen and had begun procedures to become a permanent resident of Canada. During the course of these procedures however, she went to the U.S. for a period of eight hours and when she tried to return a Special Inquiry Officer examined her and ordered her deported. Here the Board stated: ${ }^{79}$

... the Court feels that the application of the letter of the law would, in this case, be unduly harsh .... Exercising its equitable jurisdiction under section 15(1)(b)(ii), the Court orders that the execution of the order of deportation be stayed for a period of one month and that the appellant be assessed as soon as practicable as per the appro. priate schedule of the Immigration Regulations ....

Similarly in the Quarcini case, where the appellant was a merchant whose occupation required him to make frequent trips into Canada. During one such trip in 1961 he was deported on the ground that he had been convicted of a crime involving moral turpitude in his home country. However, the conviction had taken place in 1941 and since then he had been able to nullify his plea of guilty. In view of this he appealed the deportation order on the ground that the fact on which the order was based, did not exist. In this case the Board stated that it "lacks jurisdiction to decide on a deportation order made in 1961," but it granted relief ". . . by virtue of the jurisdiction conferred upon it by section 15(1)(b)(ii)." 80

Although the reasons for granting relief in the Aina case seem to be somewhat diffuse, they do give some further support to this principle.

\footnotetext{
73 Dr. Chung Ming Lu v. Minister of Manpower and Immigration (1970) 2 I.A.C. 60.

74 Rafik v. Minister of Manpower and Immigration (1969) 1 I.A.C. 138.

75 Graham v. Minister of Manpower and Immigration (1970) 1 I.A.C. 53.

76 Dakovic, supra. n. 57; Aly, supra, n. 37; Vincent, supra, n. 71; Lau, supra, n. 25; Gioulekas, supra, n. 15; and Kim v. Minister of Manpower and Immigration (1970) 3 I.A.C. 33.

77 Kim, supra, n. 76 at 63.

78 Kritikos, supra, n. 51 at 2.

79 Lotero-Isaza, supra, n. 71 at 3.

so Quarcini v. Minister of Manpower and Immigration (1969) 1 I.A.C. 38.
} 
In that case the Board recognized that ". .. as a result of the examination requested, both the appellant and his wife were found to be admissible as immigrants. ..." 81 In granting relief the Board said "it would be inhumane to force the appellant to terminate his employment, separate him from his wife and incur the expense involved to return to Canada."82

\section{The Role of "National Interest"}

Section 15 of the Immigration Appeal Board Act is a statutory exception to the generally exclusionary nature of the Immigration Act. Indeed, it can only be invoked by one who has already been found to have violated the Immigration Act. Accordingly, the Board has recognized that if Immigration Regulations are not to be flaunted with impunity, it must be selective in invoking section 15 . Thus the Chairman states: ${ }^{83}$

The Immigration Act and the Immigration Appeal Board Act are in pari materia, and the latter statute must be interpreted in such a way as to modify, where appropriate, but not destroy, the former. The Immigration Act and Regulations are the law; section 15 cannot be used irresponsibly to destroy the law-it is law, but not the law. To hold otherwise would result in chaos.

In determining those exceptional cases which warrant invocation of section 15 , the Board has occasionally alluded to the "national interest". This is in accord with the recommendation of Mr. Sedgwick that the discretion of section 15 be exercised only where ". . . such action is consistent with the national interest and established immigration policy."84 In the Pagan case the Board said:85

Public policy is an overriding consideration in all appeals where a claim to equitable relief under any of the subparagraphs of section $15(1)$ is made . . , the security and welfare of the people of Canada is always a consideration.

In the Tsemanakis case, the Board identified "the economic and security interests of the country" as two considerations of the national interest. ${ }^{86}$

\section{(a) The security interest}

In the Bourret case, where the appellant had been a member of the Fair Play for Cuba Committee and a Castro sympathizer, the Board stated that the "security risk" issue was the ". . . overriding consideration." 87 In this case however, the Board found that the appellant had been motivated by genuine sympathy for the Cubans to better their lot, that there was no evidence of either of the appellants being communist party members or having been indoctrinated into the party and that since his return to Canada, the male appellant had "been voluntarily interrogated by the Royal Canadian Mounted Police and had volunteered to be fully interrogated by the Federal Bureau of Investigation."88 In the result, the Board quashed the deportation order. By way of contrast, in another case where the appellant was a "fugitive from justice" with a lengthy criminal record, the Board held that it would be ". . . contrary to the interests of

\footnotetext{
s Aina, supra, n. 52 at 54.

82 Id. at 53.

so Scott, supra, n. 3 at 130

s4 Sedgwick, supra, n. 4 at 7.

ss Pagan, supra, n. 21 at 30.

ss Tsemanakis, supra, n. 49 at 138 .

87 Bourret, supra, n. 41 at 75.

ss Id. at 76 .
} 
this country to allow him to remain."89 In the Segura and Solorzano case the appellants were Guatamalan nationals who had been expelled from Guatamala and Mexico for revolutionary activities. The Board feared that they might continue their activities in Canada, and therefore ". . . in the public interest, the Board orders that the Deportation Orders . . . be executed as soon as practicable."90

\section{(b) The economic interest}

The economic interest appears to turn on the appellant's employment prospects and the importance of his occupation and skills to the Canadian economy. In the Peterson case, the Board was influenced by evidence that there existed ". . . a great demand for skilled newspapermen in Canada."91 Similarly, in the Chung Ming $L u$ case, the Board described the appellant as an "eminent scholar" who ". . . has much to offer Canada in the academic field."92 In both cases, the Board quashed the deportation orders.

In the Kim case, the Board dismissed the appeal because the appellant, a seaman, was "... not vital to any Canadian interest."93 And in the Dakovic case, the Board dismissed the appeal and commented "... his services are not vital to the Canadian economy."94

\section{CONCLUSIONS}

This analysis of the cases shows that in the Board's five year history, a fairly clear framework of guidelines has evolved for two of the three parts of the section. It is impossible to identify guidelines under subsection 15(1)(a) since only two of the available judgments were made under it. This gap however, is of little significance in view of the Chairman's statements that the circumstances to be considered under subsection 15(1)(a) are similar to those under subsection 15(1)(b)(ii).

The guidelines that the Board has evolved under section 15(1)(b)(ii) are impressive. The Board's regard for family considerations, for considerations of rootedness, for considerations that arise strictly out of technicalities in law as well as its consideration for the subjective factors of an appeal, appear to be very close to the legislature's strong and unanimous concern that the Board act in a compassionate and humane way. For the Board to go much further would threaten the exclusionary nature of the immigration laws, and that, Parliament did not intend.

The guidelines under subsection $15(1)(b)(i)$ are less impressive. Here the Board has determined that the onus for establishing the certainty of the claim that ". . . he will be punished, for an activity of a political character or will suffer unusual hardship" rests entirely with the appellant. The degree of this certainty is high, although exactly how high, is not clear. Punishment is defined as punishment by the state and according to law. An activity takes on a political character only when it challenges governmental authority in a public way. And the unusualness of a hardship is defined according to the appellant's situation in his home country.

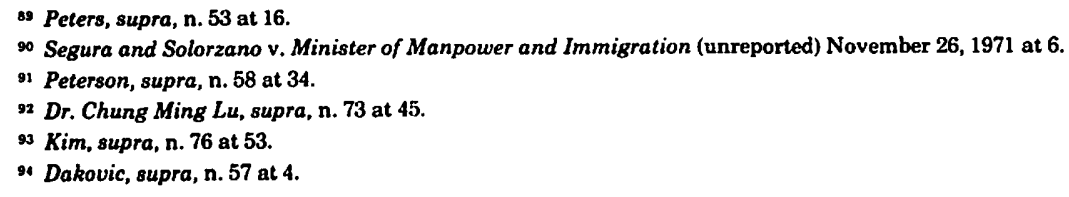


There are several issues in this body of guidelines that deserve attention. The first is the reliance on law. The board has established that for an appellant to obtain relief on the grounds that he ". . . will be punished for activities of a political character ....," he must prove that such punishment will take place in accordance with law. But is it not true that in the police state realities of the twentieth century, many "punishments" take place with the authorization of government but without regard to law, and do not some of these "atrocities" occur respectably cloaked in the mantle of kafkaesque trials and sham legality? The Board has supported its position by stating that: ${ }^{95}$

The Courts of one country, ... cannot pronounce as to the administration of justice by courts of any other country .... . To do so is not only beyond the competence of this court, but would be an unwarrantable and shocking departure from the doctrine of the comity of nations.

Admittedly, some respect for the "doctrine of the comity of nations" is appropriate, but we would submit that a blind adherence to it, would not be in accord with the legislature's humanitarian and compassionate concern.

The second issue is the Board's interpretation of "an activity of a political character." It has established that such an activity is a public challenge to a government's authority. We would submit that some private challenges are activities of a political character as well. For example, to desert the military or to refuse to serve in it could be 'political' depending on the motivation. If such an act were motivated by the desire to pursue some private interest, like starting a business, then it need not be a political act, but if it were motivated by a fundamental disagreement regarding the political objective for which the military forces were being used, then, we would submit, it should be construed as an "activity of a political character."

A third issue is the Board's interpretation of "unusual hardship." It has established that the "unusualness" of a hardship is determined according to the appellant's situation in his home country. According to this definition it is almost impossible to conceive of a hardship that would be unusual. Not surprisingly, there is only one available judgment in which relief was granted on this ground, and that was an exception to this principle. ${ }^{96}$ We would submit that the Board modify this principle by identifying certain hardships as "unusual" and establishing these as regular exceptions to the principle.

The fourth issue relates generally to the Board's procedural requirements and particularly to its requirement that the certainty-of punishment for activities of a political character or unusual hardshiphas to be established according to the standard rules of evidence. In her Special Lecture, the Chairman stated that the Board:97

... functions as a court, the adversary system prevails at all its hearings, it follows, though not rigidly, ordinary court procedure, it applies so far as possible, the ordinary rules of evidence.

In view of Parliament's apparent intent of having an efficient procedure for the application of humanitarian and compassionate considerations

9s Pagan, supra, n. 21 at 17.

96 Daniolos, supra, n. 59.

97 Scott, supra, n. 3 at 121. 
to the cases, one wonders whether the Board's procedural requirements are in proper perspective.

Implicit in several of these issues is a criticism of an "excessive legalism". The Board's concern with "legalism" arises of course out of its self-image as a court. It derives this image partly from a literal construction of section 7(1) of the Act which states, "the Board is a Court of Record ...," and partly from the Board's attributes which the Chairman describes as follows: 98

It has all the attributes of a Court; it is entirely independent of ministerial or departmental controls; its members are appointed for life during good behaviour; in my view its decisions are not subject to review by any provincial court by way of prerogative writ; it has sole and exclusive jurisdiction in its field and an appeal lies from its decisions to the Supreme Court of Canada on any question of law including a question of jurisdiction.

This image becomes even more disturbing when the chairman states that, "... since the Board is a court ...., its discretion can only be judicial discretion," 99 which, she says, is not the kind "formerly exercised by the Minister." 100 In describing this further, the Chairman says:101

... judicial discretion bears no relationship to ministerial or executive clemency ... the interpretation of the subjective words 'compassionate' and 'humanitarian' must be made objectively, that is on proof of reasonable not sentimental or emotional grounds and that proof must be in accordance with the ordinary rules of evidence, except as to admissibility.

Formerly, of course, the discretion could be exercised on whatever grounds the Minister deemed appropriate. And in creating the Board, it seemed that Parliament intended merely to transfer the discretionary powers from the Minister to a Board and to regularize the grounds for their application. But there is no indication that Parliament intended to restrict them in any way. In the words of one former Immigration Minister: 102

This bill meets a need that was felt by all Ministers of Immigration, that is, to unload themselves ... of their discretion on an organization of officials or commissioners.

The desired regularization was encouraged initially by having the statute divided into three separate parts. It was further encouraged by the suggestion for the internal development of a framework of rules. This suggestion came from Mr. Sedgwick, whose recommendations formed the basis of the new Immigration Appeal Board Act, and was later endorsed by the Board's Chairman. However, the rules that the Board has developed are rooted in its self-image as a Court. And although the restrictive character of this image is not apparent in the rules under subsection 15(1)(b)(ii), it has imposed serious restrictions on subsection 15(1)(b)(i). We would submit that with respect to subsection $15(1)(b)(i)$, it has thwarted the intent of Parliament and that the Board's image as a Court is not well-founded.

In spite of these criticisms, we recognize that the pursuit of the "optimum balance" between ensuring predictability and "uniformity in decisions" on the one hand, and dealing with each case on the basis of its

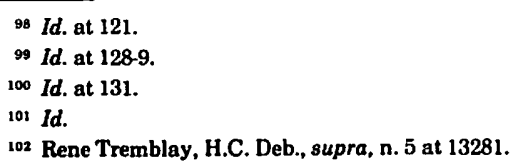


own merits on the other hand, is fraught with unending difficulties. We agree with the Chairman, when she said in her Special Lecture as she began discussion of section 15, "the interpretation and administration of justice under this section is by far the most difficult problem confronting the Board."103 We would commend the Board for making a serious attempt to exercise its discretion according to a set of guidelines and although we submit that several of the guidelines are at variance from the intent of Parliament, we would say that on the whole the Board has done well. 